\title{
Preceding infection as an important risk factor for ischaemic brain infarction in young and middle aged patients
}

\author{
JAANA SYRJÄNEN， VILLE V VALTONEN， MATTI IIVANAINEN， MARKKU KASTE, \\ JUSSI K HUTTUNEN
}

\begin{abstract}
The role of preceding infection as a risk factor for ischaemic stroke was investigated in a case-control study of 54 consecutive patients under 50 years of age with brain infarction and 54 randomly selected controls from the community matched for sex and age. Information about previous illnesses, smoking, consumption of alcohol, and use of drugs was taken. A blood sample was analysed for standard biochemical variables and serum cholesterol, high density lipoprotein cholesterol, triglyceride, and fasting blood glucose concentrations determined. Titres of antimicrobial antibodies against various bacteria, including Staphylococcus, Streptococcus, Yersinia, and Salmonella and several viruses were determined. Febrile infection was found in patients during the month before the brain infarction significantly more often than in controls one month before their examination (19 patients $\mathrm{v}$ three controls; estimated relative risk 9.0 (95\% confidence interval 2.2 to 80.0 )). The most common preceding febrile infection was respiratory infection ( $80 \%)$. Infections preceding brain infarction were mostly of bacterial origin based on cultural, serological, and clinical data. In conditional logistic regression analysis for matched pairs the effect of preceding febrile infection remained significant (estimated relative risk $14.5(95 \%$ confidence interval 1.9 to 112.3$)$ ) when tested with triglyceride concentration, hypertension, smoking, and preceding intoxication with alcohol.

Although causality cannot be inferred from these data and plausible underlying mechanisms remain undetermined, preceding febrile infection may play an important part in the development of brain infarction in young and middle aged patients.
\end{abstract}

\section{Introduction}

Several factors, including arterial hypertension, cardiac diseases, hyperlipidaemia, high fibrinogen concentrations, diabetes mellitus, a high intake of alcohol, a preceding incident of intoxication with alcohol, and smoking are associated with an increased risk of brain infarction..$^{1-7} \mathrm{~A}$ relation may also exist between various infections and brain infarction. Cerebral infarction is a well known complication of bacterial endocarditis, ${ }^{89}$ meningitis, ${ }^{1011}$ and meningovascular syphilis. Other infections that are more common in the population may, however, also be implicated. Thus several case reports and studies based on a few patients have suggested that preceding respiratory infection is a risk factor for brain infarction, especially in

\footnotetext{
Department of Bacteriology and Immunology, University of Helsinki, Haartmaninkatu 3, 00290 Helsinki, Finland
}

JAANA SYRJÄNEN, MD, research fellow

Second Department of Medicine and Department of Neurology, Helsinki University Central Hospital

VILLE V VALTONEN, MD, consultant in infectious diseases

MATTI IIVANAINEN, $M D$, associate professor

MARKKU KASTE, MD, senior lecturer in neurology

National Public Health Institute, Helsinki

JUSSI K HUTTUNEN, MD, professor

Correspondence to: Dr Syriänen. children and young adults. ${ }^{12-17} \mathrm{We}$ recently reported an association between cerebral infarction and increased serum bacterial antibody titres in young adults. ${ }^{18}$ The role of preceding infections in the development of ischaemic stroke has not, however, been systematically studied. In our case-control study the prevalence of preceding infections in 54 consecutive patients with brain infarction aged under 50 was examined and compared with that in control subjects matched for age and sex.

\section{Subjects and methods}

We studied all patients with brain infarction under the age of 50 admitted to Helsinki University Central Hospital between June 1985 and August 1986. The hospital serves about one million inhabitants, and almost all young patients with acute stroke in the district are admitted here. The patients were examined by one of us (JS) on the ward in the emergency department, where all patients admitted from this department spend their first night. All admissions to this hospital are recorded in a register, which was examined daily by JS. The patients were entered into the study if they had localised cerebral symptoms and signs suggesting cerebral ischaemia lasting more than 24 hours or if an infarction was verified by a computed tomogram taken on admission. All patients had computed tomography within a few days after the onset of symptoms. Patients with other causes of localised cerebral symptoms, such as haemorrhage, were excluded.

During the 15 months of the study 54 patients fulfilled the criteria for inclusion. They comprised 33 men and 21 women, and their ages ranged from 17 to 49 years (mean 37.7 years). Cerebral infarction occurred in the distribution of the middle cerebral arteries in 38 patients, in that of the posterior cerebral arteries in five, and in that of the vertebrobasilar arteries in 11. In 36 patients the computed tomogram showed one ischaemic lesion, and in seven two or more ischaemic lesions. In the remaining 11 patients the computed tomogram on admission was normal but the clinical picture and the course of the disease were compatible with a diagnosis of brain infarction. Among patients with normal computed tomograms five had a brain stem infarction and in the remaining six patients the time from the onset of symptoms to the scan was 24 hours or less. One of the patients had experienced one earlier ischaemic stroke. Two patients died during the first week after admission. No other deaths occurred during the three months of observation.

The controls were matched with patients for sex and age (within one year), resulting in 54 case-control pairs. Their ages ranged from 18 to 49 years (mean 37.8 years). The controls were selected at random from the official register of inhabitants of Helsinki, where the names, dates of birth, and addresses of all Helsinki's inhabitants are recorded. To find enough controls two subjects matched for sex and age to every patient were initially invited to the study. As the first 15 patients were matched by two controls- that is, the rate of participation was higher than expected-we decided to invite only one control for each subsequent patient; if the control refused to participate we invited another. A letter of invitation was sent to the control subject as soon as the patient was admitted to the hospital. After the letter was presumed to have arrived the controls were contacted by telephone and an appointment made. Altogether 77 controls were invited and 69 of them $(90 \%)$ agreed to participate; seven of those who refused to participate said that they were healthy and could not participate because of lack of time, and one had rheumatoid arthritis and could not come because of difficulties in moving. The controls were examined within two to four weeks after their patient was admitted. All the controls were asked to come to the examination regardless of any acute illness, and none of them was excluded owing to illness. The purpose was to conduct a case-control study matched one to one. The first 15 patients, however, had two controls; we excluded all of the second controls of these 15 patients and took into the analyses only the control who was examined first.

All the controls were examined by the same physician (JS). Although the invited controls were not matched with patients for socioeconomical state, 
no significant difference existed for this factor. When divided into three socioeconomic classes (professionals and employees in upper management, employees in middle management and workers, and vagrants, who were homeless people without a job) patients and controls were in identical classes in 39 pairs, patients were in a higher class in six, and controls were in a higher class in nine $(p>0.5)$; only one patient was in the lowest class. Detailed information about associated illnesses, preceding infections, consumption of alcohol, smoking habit, and use of oral contraceptives and other drugs was obtained in the same way from all the controls and the patients or their relatives, or both. Laboratory determinations included haemoglobin concentration; packed cell volume; mean corpuscular volume; total and differential white cell count; thrombocyte count; erythrocyte sedimentation rate; serum electrolyte concentrations; cholesterol, high density lipoprotein cholesterol, triglyceride, and fasting blood glucose concentrations; activities of transaminases and $\gamma$-glutamyl-transferase; and analysis of urine. A chest $x$ ray film and electrocardiogram were also obtained. The patients' serum lipid concentrations were measured twice, initially and three months after their stroke. Consultation with a cardiologist was sought for 20 patients when cerebral embolism was suspected.

Serum samples-Serum samples for serological tests were drawn from patients three times. The first sample was taken as soon as possible after the patient was admitted and the diagnosis of cerebral infarction verified (mean 36 hours after admission). The time from the onset of symptoms to the taking of the first sample ranged from 0 to six days (mean two days). The second sample was drawn two to three weeks later and the third three months after the stroke. Two serum samples were drawn from the controls two to three weeks apart. All samples were kept at $-20^{\circ} \mathrm{C}$ until analysed. A sample was not obtained from one patient who died soon after the stroke.

Serological methods-Antimicrobial antibodies were assayed with established methods. The criterion for a positive bacterial or viral serological result was either a fourfold change in titre between the paired serum samples taken two to three weeks apart or a high titre above the 99th percentile in a healthy Finnish population, as determined in the same laboratory, ${ }^{19}$ or both The bacterial antibodies determined and their upper 99th percentile limits were antistreptolysin $\mathrm{O}, 770$ Todd units ${ }^{20}$; antideoxyribonuclease $\mathrm{B}, 1 / 600$ antistaphylolysin, $4.0 \mathrm{IU} / \mathrm{ml}$; teichoic acid antibody (measured by double diffusion precipitation), 1/8; agglutinating antibodies against Yersinia enterocolitica serotypes 3 and 9 and salmonella $O$ antigens $(4,5,12 ; 9,12$; and $6,7), 1 / 320$; antibodies against antigen specific to the genus Chlamydia (by

TABLE I-Fever and its causes during one month before ischaemic stroke (patients) or examination (controls) for 54 case-control pairs

\begin{tabular}{|c|c|c|c|c|}
\hline & $\begin{array}{c}\text { No of } \\
\text { patients }\end{array}$ & $\begin{array}{l}\text { No of } \\
\text { controls }\end{array}$ & $\begin{array}{l}\text { Relative risk ( } 95 \% \\
\text { confidence interval) }\end{array}$ & p Value \\
\hline Fever $\left(\geqslant 37.5^{\circ} \mathrm{C}\right)$ & 21 & 3 & $10 \cdot 0(2 \cdot+$ to $88 \cdot 2)$ & $<0.001$ \\
\hline Respiratory infection with fever & $17^{\star}$ & $2+$ & & \\
\hline Endocarditis & 2 & & $9 \cdot 0(2 \cdot 2$ to $80 \cdot 0)$ & $<0.001$ \\
\hline Enteritis & & 1 & & \\
\hline Unknown, but possible infection & 2 & & & \\
\hline
\end{tabular}

*Two patients also had otitis media, two sinusitis, three pneumonia, and one urinary infection.

tOnecon. complement fixation), 1/32; and Mycoplasma pneumoniae antibodies (by complement fixation), 1/512. Antibodies against adenovirus, influenza viruses $A$ and $B$, parainfluenza viruses 1 and 3 , respiratory syncytial virus, Coxsackie virus B5, rotavirus, cytomegalovirus, mumps and measles viruses, varicella zoster, and herpes simplex were determined by complement fixation. Antibodies to rubella were determined by single radial haemolysis and to Epstein-Barr virus by immunofluorescence.

Statistical methods-For the matched pairs mean differences and estimated relative risks (odds ratio) were computed as quantitative measures of discrepancy together with their $95 \%$ confidence intervals. The confidence interval for the mean difference was based on the standard error for pairwise differences. ${ }^{21}$ The confidence interval for the relative risk was computed from the tail probabilities of the binomial distribution. ${ }^{22}$ Equality of proportions was tested with McNemar's test or exact binomial probabilities. Estimates of relative risk (odds ratio) adjusted for confounding factors were computed from a conditional logistic regression model for matched data. ${ }^{22}$ The model was fitted with a procedure in the biomedical computer program (BMDP) such that each pair constituted an observation, each response was positive, no constant existed in the model, and the explanatory variables were differences in the corresponding values between cases and controls. Subgroups of cases were compared by unpaired differences in means or proportions. ${ }^{21}$

\section{Results}

\section{INFECTION AS A RISK FACTOR}

The prevalence of febrile infections during the month preceding the ischaemic stroke in the patients was significantly higher than that during the month preceding the examination of their controls. Thus 21 of the 54 patients but only three of the 54 controls had had a fever $\left(\geqslant 37.5^{\circ} \mathrm{C}\right)$ during the preceding month (relative risk $10 \cdot 0,95 \%$ confidence interval $2 \cdot 4$ to $88 \cdot 2)$. The corresponding figures for the preceding week were 14 among patients and two among controls (relative risk 7.0 (1.6 to 63.4)). Definite infection was the cause of fever in 19 patients and three controls (relative risk $9.0(2.2$ to 80.0$))$ (table I). Within one month before the stroke or the examination 14 patients and three controls with infectious symptoms either visited a general practitioner or were in hospital, where their raised temperatures were recorded; seven patients had measured their temperatures only at home. Antibiotics had been prescribed within the preceding month to the patients more often than to their controls (14 patients $v$ three controls, relative risk $4 \cdot 7(1 \cdot 3$ to $25 \cdot 3)$ ). Probable or proved (by culture) bacterial infection was found in 12 patients and two controls (relative risk $6.0(1 \cdot 3$ to $55 \cdot 2)$ ) (table II). Except in one patient, bacterial infection had been diagnosed before the patients' symptoms of stroke or the controls' examination by a general practitioner or a hospital physician who did not participate in this study. Sphenoidal sinusitis was diagnosed in the remaining patient from a computed tomogram on admission (case 6 in table II). Pneumonia or endocarditis preceded the brain infarction in five patients, whereas none of the controls had a systemic bacterial infection within one month before the examination.

A complete history of previous infections was obtained from all patients and controls. Patients reported recurrent sinusitis (two or more episodes

TABLE II-Probable or proved (by culture) bacterial infection during one month before ischaemic stroke (patients) or examination (controls)

\begin{tabular}{|c|c|c|c|c|c|c|c|c|}
\hline $\begin{array}{l}\text { Case } \\
\text { No }\end{array}$ & $\begin{array}{c}\text { Age } \\
\text { (years) }\end{array}$ & Sex & Fever & Infection & Bacterial cause & Basis of diagnosis & $\begin{array}{l}\text { Other preceding } \\
\text { factors }\end{array}$ & $\begin{array}{l}\text { Possible cause } \\
\text { of infarction }\end{array}$ \\
\hline \multicolumn{9}{|c|}{ Patients ${ }^{\star}$} \\
\hline 1 & 44 & M & Yes & Otitis media and externa & Antistreptolysin () titre high & Clinical state & None & Unknown \\
\hline 2 & 17 & $\mathrm{~F}$ & Yes & Otitis media and sinusitis & Antideoxyribonuclease $\mathrm{B}$ titre high & Clinical state and sinus ultrasonogram & None & Unknown \\
\hline 3 & 26 & $\mathrm{~F}$ & No & Purulent otitis externa & Unknown & Clinical state & None & Atherosclerosist \\
\hline+ & 22 & M & Yes & Sinusitis & Unknown & Sinus $x$ ray film & None & Unknown \\
\hline 5 & 45 & $M$ & Yes & Sinusitis & Unknown & Sinus $x$ ray film and punctures of maxillary sinus & None & Atherosclerosisł \\
\hline 6 & 39 & $M$ & No & Sinusitis & Unknown & Sinus $x$ ray film and computed tomogram & None & Unknown \\
\hline 7 & 48 & $M$ & Yes & Pneumonia & Fourfold change in antistreptolysin () titre & Chest $x$ rav film & None & Unknown \\
\hline 8 & 31 & $M$ & Yes & Pneumonia & Unknown & Chest $x$ ray film & None & Unknown \\
\hline 9 & 41 & $\mathrm{~F}$ & Yes & Pneumonia & Fourfold change in antistaphylolysin titre & Chest $x$ ray film & Alcohol intoxication & Unknown \\
\hline 10 & 41 & $\mathrm{~F}$ & Yes & Urinary infection & Klebsiella & Culture of urine & None & Unknown \\
\hline 11 & 49 & M & Yes & Endocarditis & Streptococcus sanguis & Culture of bleod & None & Septic embolism \\
\hline 12 & 38 & $M$ & Yes & Endocarditis & $\begin{array}{l}\text { P-Haemolytic streptococcus } \mathrm{G} \\
\text { Fourfold change in antistreptolysin O titre }\end{array}$ & Culture of bloed & None & Septic embolism \\
\hline \multicolumn{9}{|c|}{ Controls } \\
\hline 15 & 35 & $\mathbf{M}$ & Yes & Sinusitis & Unknown & Sinus $x$ rav film & & \\
\hline 16 & 39 & $\mathbf{F}$ & Yes & Enteritis & Campylobacter jejuni & Culture of stools & & \\
\hline
\end{tabular}

*Twelve patients $v$ two controls, relative risk $6.0(95 \%$ confidence interval $1 \cdot 3$ to $55 \cdot 2) ; \mathrm{p}<0.02$.

†Patient had insulin dependent diabetes with asymmetrical peripheral arterial pulsations.

$\ddagger$ Patient had slight irregularity of vessel lumen at proximal end of internal carotid artery shown on aortocervical angiography. 
during their life) more often than the controls (nine patients $v$ two controls; relative risk 8.0 (1.1 to $354 \cdot 6)$ ). Likewise, a history of recurrent tonsillitis was more common among the patients than the controls, but the difference was not significant (22 patients $v 12$ controls; relative risk $2 \cdot 3(0 \cdot 9$ to $6 \cdot 0)$ ). No difference was found between patients and controls with a history of recurrent otitis media.

Serological evidence for a recent bacterial infection was obtained in 19 patients but only seven controls (relative risk $5 \cdot 0(1.4$ to $27 \cdot 0)$ ) (table III). Sixteen patients had a positive result in only one of the tests, whereas three patients had a positive finding in two tests. These patients included one with a positive finding in the tests for antistaphylolysin and antideoxyribonuclease $B$, one with positive results for antideoxyribonuclease $B$ and yersinia 9 , and one with positive results for yersinia 3 and salmonella. Five of the controls had a positive finding in one of the tests, whereas the two others had a positive finding in tests for both yersinia 3 and yersinia 9. In one patient the positive result could be explained by an infection that had begun after the stroke (bedsores with staphylococcal infection and positive results on serological testing for staphylococci). All other patients with positive results on serological testing had probably had an infection before their brain infarction.

No difference was found between patients and controls in the results of viral serological examination. One patient showed a fourfold change in titre of antibody to influenza A virus. She had had fever and respiratory symptoms beginning three days before her brain infarction, but she also had a high titre of antibody to yersinia $9(1 / 640)$ in all three samples. No change in titres of antibodies to viruses was found in controls, and the distribution of high titres was similar in the two groups.

Erythrocyte sedimentation rate measured from 24 to 72 hours after the brain infarction was raised (above $15 \mathrm{~mm}$ in the first hour) in 18 patients and seven controls (relative risk $2 \cdot 8(1 \cdot 1$ to $9 \cdot 0)$ ). Patients with probable or proved bacterial infection shown in table II more commonly had raised erythrocyte sedimentation rates than the remaining patients $(8 / 12 v 10 / 42$; difference $43 \%(12-74 \%)$ ). Leucocyte values above $10 \times 10^{9} / 1$ were found in 14 patients and one control (relative risk $13 / 0=\infty(3 \cdot 0$ to $\infty)$ ).

TABLE III-Positive results from bacterial serological tests in 53 case-control pairs ${ }^{\star}$

\begin{tabular}{lcc}
\hline & $\begin{array}{c}\text { No of patients } \\
(\mathrm{n}=19) \dagger\end{array}$ & $\begin{array}{c}\text { No of controls } \\
(\mathrm{n}=7) \ddagger\end{array}$ \\
\hline $\begin{array}{l}\text { Antistreptolysin O } \\
\text { Antideoxyribonuclease B }\end{array}$ & 3 & 2 \\
Antistaphylolysin & 3 & 2 \\
Teichoic acid antibody & 2 & \\
Yersinia 3 or 9 & 6 & 5 \\
Salmonella & 1 & \\
\hline
\end{tabular}

«Nineteen patients $v$ seven controls, relative risk 5.0 (95\% confidence interval 1.4 to 24.0 ); $p<0.01$.

Three patients gave a positive result in two tests (see text).

†Two controls gave a positive result in two tests (see text)

\section{OTHER RISK FACTORS}

The patients and their controls were also interviewed and examined for other established or suspected risk factors of ischaemic stroke (tables IV and V). Packed cell volumes and the prevalence of migraine showed no difference between the patients and controls. The prevalence of febrile and bacterial infections among patients who were intoxicated with alcohol before the brain infarction, heavy drinkers, current smokers, or diabetics did not differ significantly from that among patients without such risk factors.

Serum triglyceride concentrations were higher in the patients than the controls both immediately after the ischaemic stroke and three months later (tables IV and V). The high density lipoprotein cholesterol concentration was lower in the patients immediately after the ischaemic stroke than in the controls, but the difference was not evident three months later (table V). Patients with a recent bacterial infection had lower mean high density lipoprotein cholesterol concentrations than patients without such infection both immediately after the ischaemic stroke $(0.80 \mathrm{mmo} / / \mathrm{v} 1.15 \mathrm{mmol} / \mathrm{l}$ ( $95 \%$ confidence interval for mean difference 0.17 to $0.53 \mathrm{mmol} / \mathrm{l})$ ) and three months later $(0.99 \mathrm{mmol} / \mathrm{l} v 1.25 \mathrm{mmol} / \mathrm{l}(0.03$ to $0.49 \mathrm{mmol} / \mathrm{l})$ ).

Conditional logistic regression analysis for matched pairs was carried out to investigate the association between preceding febrile infection and ischaemic stroke when other risk factors of stroke were controlled for. The effect of preceding febrile infection remained significant when all the risk factors that were found to be associated with ischaemic stroke in univariate analysis were included as covariates in the logistic model (table VI). Smoking and preceding intoxication with alcohol were significantly more common
TABLE IV-Risk factors for ischaemic stroke in patients and controls

\begin{tabular}{|c|c|c|c|}
\hline Risk factor & $\begin{array}{c}\text { No of } \\
\text { patients }\end{array}$ & $\begin{array}{l}\text { No of } \\
\text { controls }\end{array}$ & $\begin{array}{l}\text { Relative risk ( } 95 \% \\
\text { confidence interval) }\end{array}$ \\
\hline Preceding febrile infection & $19 / 54$ & $3 / 54$ & $9 \cdot 0(2 \cdot 2 \text { to } 80.0)^{\star \star \star}$ \\
\hline Hypertension $\dagger$ & $12 / 54$ & $2 / 54$ & $6.0(1.3 \text { to } 55.2)^{\star \star}$ \\
\hline Coronary heart disease $\ddagger$ & $4 / 54$ & $0 / 54$ & $\infty(0.7$ to $\infty)$ \\
\hline Hypercholesterolaemia \{ & $8 / 47$ & $5 / 47$ & $1.8(0.4$ to $8 \cdot 2)$ \\
\hline \multicolumn{4}{|l|}{ Raised cholesterol to HDL cholesterol } \\
\hline ratio & $14-47$ & $6 / 47$ & $3.0(0.9$ to 12.8$)$ \\
\hline Hypertriglyceridaemia $\mid$ & $13 / 46$ & $2 / 46$ & $6.5(1.5 \text { to } 59.4)^{\star \star}$ \\
\hline Raised blood glucose concentrationft & $3 / 51$ & $0 / 51$ & $\infty(0.4$ to $\infty)$ \\
\hline Insulin dependent diabetes & $2 / 54$ & $0 / 54$ & $\infty(0.2$ to $\infty)$ \\
\hline Thrombocytosis $\left(>360 \times 10^{9} / 1\right)$ & $4 / 52$ & $0 / 52$ & $\infty(0.7$ to $\infty)$ \\
\hline Preceding migraine attack & $2 / 54$ & $0 / 54$ & $\infty(0 \cdot 2$ to $\infty)$ \\
\hline Oral contraceptive use & $4 / 21$ & $3 / 21$ & $1.5(0.2$ to 18.0$)$ \\
\hline \multicolumn{4}{|l|}{ Smoking state: } \\
\hline \multicolumn{4}{|l|}{ Current smokers: } \\
\hline Men & $24 / 33$ & $11 / 33$ & $5.3(1.5 \text { to } 28.6)^{\star \star}$ \\
\hline Women & $3 / 21$ & $7 / 21$ & $0.4(0.1$ to 1.9$)$ \\
\hline \multicolumn{4}{|l|}{ Heavy smokers ( $>20$ cigarettes/day): } \\
\hline Men & $6 / 33$ & $1 / 33$ & $6.0(0.7$ to $275 \cdot 8)$ \\
\hline Women & $1 / 21$ & $2 / 21$ & $0.5(0.0$ to 9.6$)$ \\
\hline Preceding intoxication with alcohol & $12 / 54$ & $2 / 54$ & $6.0(1.3 \text { to } 55 \cdot 2)^{\star \star}$ \\
\hline Men & $10 / 33$ & $2 / 33$ & $5.0(1.1 \text { to } 46.9)^{\star}$ \\
\hline Women & $2 / 21$ & $0 / 21$ & $\infty(0.2$ to $\infty)$ \\
\hline \multicolumn{4}{|l|}{ High intake of alcohol $\$$ : } \\
\hline Men & $8 / 33$ & $2 / 33$ & $4.0(0.8$ to $38 \cdot 7)$ \\
\hline Women & $1 / 21$ & $1 / 21$ & $1.0(0.0$ to 78.4$)$ \\
\hline
\end{tabular}

$\mathrm{HDL}=$ High density lipoprotein

${ }^{\star} \mathrm{p}<0.05$.

$\star \star \mathrm{p}<0.02$.

$\star \star \star \mathrm{p}<0.001$.

†Systolic blood pressure $>150 \mathrm{~mm} \mathrm{Hg}$ or diastolic blood pressure $>100 \mathrm{~mm} \mathrm{Hg}$ measured from one to four weeks after stroke or continuous treatment with antihypertensive drugs.

fAngina pectoris or myocardial infarction.

SSerum cholesterol concentration $>7.0 \mathrm{mmol} / \mathrm{l}$ in fasting blood sample (sample taken three months after stroke in patients).

Ratio $>6.0$ in fasting blood sample (sample taken three months after stroke in patients).

I Serum triglyceride concentration $>1.7 \mathrm{mmol} / \mathrm{l}$ in fasting blood sample (sample taken three months after stroke in patients).

HConcentration $>6.0 \mathrm{mmol} / \mathrm{l}$ in fasting blood sample (sample taken one week after stroke in patients).

\#Consumption of over $80 \mathrm{~g}$ of absolute alcohol over a few hours during the 48 hours before stroke examination.

CConsumption of over $300 \mathrm{~g}$ of absolute alcohol during an ordinary week (based on answers at interview).

TABLE V-Mean (SD) serum lipid concentrations (mmol/l) in patients and controls. Mean differences with $95 \%$ confidence intervals between cases and controls in matched pairs are given

\begin{tabular}{|c|c|c|c|}
\hline & \multicolumn{2}{|c|}{ Patients (time after stroke) } & \multirow[b]{2}{*}{ Controls } \\
\hline & $24-72 \mathrm{~h}$ & Three months & \\
\hline $\begin{array}{l}\text { Cholesterol } \\
\text { Mean difference }\end{array}$ & $\begin{array}{l}5.7(1.6) \\
0.1(-0.4 \text { to } 0.6)\end{array}$ & $\begin{array}{l}6.0(1.6)^{\star} \\
0.4(-0.1 \text { to } 0.9)\end{array}$ & $5 \cdot 6(1 \cdot 3)$ \\
\hline $\begin{array}{l}\text { High density lipoprotein } \\
\text { Mean difference }\end{array}$ & $\begin{array}{l}1 \cdot 1(0.3) \\
-0.2(-0.3 \text { to }-0.1)\end{array}$ & $\begin{array}{l}1 \cdot 2(0.3) \dagger \\
-0.1(-0.2 \text { to } 0.1)\end{array}$ & $1 \cdot 3(0 \cdot 3)$ \\
\hline $\begin{array}{l}\text { Triglycerides } \\
\text { Mean difference }\end{array}$ & $\begin{array}{l}1.5(1.0) \\
0.5(0.2 \text { to } 0.8)\end{array}$ & $\begin{array}{l}1.4(1 \cdot 0) \\
0.4(0.1 \text { to } 0.8)\end{array}$ & $1.0(0.4)$ \\
\hline $\begin{array}{l}\text { Cholesterol to high density } \\
\text { lipoprotein cholesterol ratio } \\
\text { Mean difference }\end{array}$ & $\begin{array}{l}5.5(1.9) \\
0.9(0.3 \text { to } 1.5)\end{array}$ & $\begin{array}{l}5 \cdot 3(1 \cdot 7) \\
0 \cdot 6(-0.0 \text { to } 1 \cdot 3)\end{array}$ & $4 \cdot 5(1 \cdot 4)$ \\
\hline
\end{tabular}

* Mean difference $(95 \%$ confidence interval) between sample taken $24-72 \mathrm{~h}$ after infarction and that taken three months after infarction $0 \cdot 4(0 \cdot 1$ to $0 \cdot 8)$.

† Mean difference ( $95 \%$ confidence interval) between sample taken $24-72 \mathrm{~h}$ after infarction and that taken three months after infarction $0 \cdot 1(0.1$ to $0 \cdot 2)$

TABLE VI-Estimated relative risks by conditional logistic regression analysis for matched pairs with febrile infection, hypertension, intoxication with alcohol, triglyceride concentration, and smoking as risk factors

\begin{tabular}{lcc}
\hline Risk factor & Relative risk & 95\% Confidence interval \\
\hline Febrile infection & 14.5 & 1.9 to 112.3 \\
Triglyceride concentration $\dagger$ & 3.9 & 1.0 to 16.2 \\
Hypertension & 14.4 & 0.8 to 248.5 \\
Intoxication with alcohol & 6.9 & 0.6 to 83.5 \\
Current smoking & 2.0 & 0.5 to 7.5
\end{tabular}

$\star$ Fever $\geqslant 37 \cdot 5^{\circ} \mathrm{C}$ during the preceding month and infectious symptoms.

tChange in risk of ischaemic stroke for one unit $(\mathrm{mmol} / \mathrm{l})$ change in triglyceride value. Patients' triglyceride values are those three months after stroke.

$\ddagger$ Systolic blood pressure $>150 \mathrm{~mm} \mathrm{Hg}$, diastolic blood pressure $>100 \mathrm{~mm} \mathrm{Hg}$, or continuous treatment with antihypertensive drugs.

treatment with antihypertensive drugs. CConsum 
only among male patients. When only the men were studied the effect of preceding febrile infection still remained significant when tested together with smoking and preceding intoxication with alcohol (relative risk $26 \cdot 6$ ( $1 \cdot 4$ to $506 \cdot 6)$ ).

\section{Discussion}

Our results suggest that a febrile infection during a preceding month is a risk factor for brain infarction. Its effect remained significant when other risk factors for brain infarction were controlled for. Such infections were of bacterial origin in most patients based on cultural, serological, and clinical data, respiratory infections being the most common.

The patients consisted of all patients with ischaemic stroke under the age of 50 admitted to Helsinki University Central Hospital. In Finland patients with strokes are generally admitted to a hospital for examinations, treatment, and rehabilitation; young and middle aged patients especially are admitted to university hospitals, where emergency neurological and neurosurgical services are available. Thus almost all of the young patients with ischaemic stroke in the district of Helsinki University Central Hospital were probably included in this study. Our patients' low mortality (4\%) is similar to that found in other studies of ischaemic stroke in young and middle aged patients. ${ }^{2324}$

Selecting control subjects requires care when studying a possible relation between infections and other disease. We decided to select our controls at random from the community. Controls acquired from the hospital are not suitable for this kind of study because infections are probably overrepresented in patients in hospital. As the rate of participation was high $(90 \%)$ refusals in the control group probably did not cause any appreciable bias. Socioeconomic state did not differ significantly between patients and controls so is not a probable explanation of our results. To exclude the possible effect of seasonal variation of respiratory infections control subjects were examined as soon as possible after their corresponding patient was admitted. We could not obtain reliable information about past infections from three patients because of their aphasia or coma, nor could it be obtained from their relatives; in the statistical analyses these patients were regarded as not having had past infection. Preceding infections were studied retrospectively in both patients and controls. All controls were asked to participate in the examination regardless of whether they happened to be acutely ill, and none of them were excluded owing to illness. Many of the patients with febrile infection (14/19) had either visited a general practitioner or been at hospital because of infection during the preceding month. Such occurrences would also probably be remembered by the controls. Furthermore, the results of bacterial serological tests supported the view of a higher prevalence of preceding bacterial infections in patients than controls.

The serological tests measured antibodies against four bacterial genuses: Streptococcus, Staphylococcus, Salmonella, and Yersinia. In most patients $(16 / 19)$ the positive antibody titres were against only one bacterial species. This observation excludes non-specific polyclonal immunostimulation and supports specific bacterial infection as a cause of the positive results. Unfortunately we did not measure antibodies against pneumococci and Haemophilus influenzae, two organisms commonly causing sinusitis and other respiratory infections. Thus a more complete set of bacterial serological tests might have yielded even more positive results in the patients. Our earlier report provided serological evidence of recent bacterial infection in patients with cerebral infarction, ${ }^{18}$ which was confirmed in this case-control study.

Several studies suggested that infections were a risk factor for stroke, ${ }^{12-1825-28}$ respiratory infections being the most common. ${ }^{12-1726}$ These studies were, however, case reports or not adequately controlled. Janaki et al reported that an infection with fever preceded cerebral infarction in 10 of their 26 patients under 20 years of age; in keeping with our results infections were mostly of bacterial origin. ${ }^{25}$ The best known example of the association of bacterial infection and stroke is infective endocarditis; cerebral infarction is a complication in $10-15 \%$ of cases of bacterial endo- carditis. ${ }^{89}$ In this study two patients $(4 \%)$ had cerebral infarction due to endocarditis.

Both preceding intoxication with alcohol ${ }^{5}$ and a high intake of alcohol ${ }^{6}$ are associated with ischaemic stroke, which agrees with our results. Hypertension is a well known risk factor for ischaemic stroke, ${ }^{129}$ which we also found. The low prevalence of hypertension and coronary heart disease among our patients is probably due to their young age and agrees with other studies in Scandinavia. ${ }^{513}$

Information on the association between high density lipoprotein cholesterol concentration and ischaemic stroke is contradictory. Although some studies have reported a low serum high density lipoprotein cholesterol concentration in patients with ischaemic stroke, ${ }^{30-32}$ others have not observed such a relation. ${ }^{33-35}$ Our results may in part explain these conflicting results. Thus high density lipoprotein cholesterol concentration was significantly lower in the patients than the controls immediately after admission to the hospital, but the difference disappeared over three months. Therefore, low high density lipoprotein cholesterol concentration in patients with ischaemic stroke may be a result rather than the cause of the disease. In agreement with several reports we found no difference in serum cholesterol concentration between patients with ischaemic stroke and controls. ${ }^{313303233}$ Data on serum triglyceride concentrations in cerebrovascular disease are limited. In agreement with a previous investigation we found significantly higher serum triglyceride concentrations in patients than controls. ${ }^{3}$ Infections are known to cause alterations in lipid values. ${ }^{36}{ }^{37}$ Indeed, our patients who had had bacterial infections had lower high density lipoprotein cholesterol concentrations than those without such a history.

Several risk factors for ischaemic stroke, such as alcohol, smoking, and diabetes, may alter susceptibility and immunity to infections. Thus a high prevalence of febrile infections among patients with brain infarction may result from a high prevalence of these underlying common risk factors for ischaemic stroke. This is not, however, a likely explanation as the prevalence of febrile infections did not differ significantly between the patients who were diabetics, smokers, heavy drinkers, or intoxicated with alcohol before the brain infarction and those who were not. Furthermore, logistic regression analysis indicated that febrile infection was a significant risk factor for brain infarction even when the effect of other risk factors was taken into account.

In our study the possible mechanisms between infection and infarction were undetermined except for those infarctions that were probably caused by septic emboli in endocarditis. Among patients with a bacterial infection during one month before the stroke (table II) only one patient had another preceding factor-namely, intoxication with alcohol-that may predispose to thrombosis. Infections may induce thrombosis and brain infarction by several mechanisms. In septicaemia and endocarditis the probable mechanism is formation of a thromboembolus, vasculitis, or disseminated intravascular coagulation. Infection in the region of neck and throat has been suggested to cause a local inflammatory arteritis of the carotid leading to cerebral infarction. ${ }^{12}$ Infection and inflammation cause many systemic effects including changes in aggregation of platelets, lysis of platelets, spasms in vascular smooth muscle, and changes in the blood coagulation system. ${ }^{38}{ }^{39}$ Immune complexes induced by the infection can cause vasculitis and platelet aggregation. ${ }^{40}$ Immunological disorders have also been suspected to play a part in atherosclerosis. ${ }^{4142}$

In conclusion, our data suggest that a preceding febrile infection is a significant and previously underestimated risk factor for brain infarction in patients under 50 years of age.

This work was supported by grants from the Finnish Cultural Foundation, the Finnish Medical Society (Duodecim), Hoechst-Fennica Research Foundation, and Orion Corporation Research Foundation. We thank Juni Palmgren, PhD, from the National Public Health Institute for her help in the statistical analyses and Mrs Marita Siren and Mrs Outi Vossi for their skilful technical help.

\section{References}

1 Dyken ML, Wolf PA, Barnett HJM, et al. Risk factors in stroke. Stroke 1984;15:1105-11 
2 Hart RG, Miller VT. Cerebral infarction in young adults: a practical approach. Stroke 1983;14:110-4.

3 Fogelholm R, Aho K. Ischaemic cerebrovascular disease in young adults. II. Serum cholesterol and triglyceride values. Acta Neurol Scand 1973;49:428-33.

4 Wilhelmsen L, Svärdsudd K, Korsan-Bengtsen K, Larsson B, Welin L, Tibblin G. Fibrinogen as a risk factor for stroke and myocardial infarction. N Engl f Med 1984;311:501-5.

5 Hillbom $M$, Kaste $M$. Ethanol intoxication: a risk factor for ischemic brain infarction. Stroke 1983; 14:694-9.

6 Gill JS, Zezulka AV, Shipley MJ, Gill SK, Beevers DG. Stroke and alcohol consumption. N Engl f Med 1986;315:1041-6.

7 Bonita R, Scragg R, Stewart A, Jackson R, Beaglehole R. Cigarette smoking and risk of premature stroke in men and women. $\mathrm{BrMed} \mathcal{J}$ 1986;293:6-8.

8 Jones RH Jr, Siekert RG, Geraci JE. Neurological manifestations of bacterial endocarditis. Ann Intern Med 1969;71:21-7.

9 Pruitt AA, Rubin RH, Karchmer AW, Duncan GW. Neurologic complications of bacterial endocarditis. Medicine 1978;57:329-43.

10 Snyder RD, Stovring J, Cushing AH, Davis LE, Hardy TL. Cerebral infarction in childhood bacterial meningitis. $\mathcal{F}$ Neurol Neurosurg Psychiatry 1981;44:581-5.

11 Igarashi M, Gilmartin RC, Gerald B, Wilburn F, Jabbour JT. Cerebral arteritis and bacterial meningitis. Arch Neurol 1984;41:531-5.

12 Bickerstaff ER. Aetiology of acute hemiplegia in childhood. Br Med F 1964;ii:82-7.

13 Hindfelt $B$, Nilsson $O$. Brain infarction in young adults with particular reference to pathogenesis. Acta Neurol Scand 1977;55:145-57.

14 Parker P, Puck J, Fernandez F. Cerebral infarction associated with Mycoplasma pneumoniae Pediatrics 1981;67:373-5.

15 Moran A, MacDonald J. Eight cases of childhood stroke. Minn Med 1985;68:675-7.

16 Tagawa T, Mimaki T, Yabuuchi H, Iwata Y, Makino A. Bilateral occlusions in the cervical portion of the internal carotid arteries in a child. Stroke 1985;16:896-8.

17 Dowd AB, Grace R, Rees WDW. Cerebral infarction associated with Mycoplasma pneumoniae infection. Lancet 1987;ii:567.

18 Syriänen J, Valtonen VV, Iivanainen M, Hovi T, Malkamäki M, Mäkelä PH. Association between cerebral infarction and increased serum bacterial antibody levels in young adults. Acta Neurol Scand 1986;73:273-8.

19 Valtonen VV, Ruutu P, Varis K, Ranki M, Malkamäki M, Mäkelä PH. Serological evidence for the role of bacterial infections in the pathogenesis of thyroid diseases. Acta Med Scand 1986;219:105-11.

20 Rose NR, Friedman H, eds. Manual of clinical immunology. 2nd ed. Washington, DC: American Society for Microbiology, 1980:431-6.

21 Gardner MJ, Altman DG. Confidence intervals rather than P values: estimation rather than hypothesis testing. BrMed F 1986;292:746-50.

22 Breslow NE, Day NE, eds. Statistical methods in cancer research. Vol I. The analysis of case-contro studies. Lyons: International Agency for Research on Cancer, 1980:162-5, 247-79.
23 Kaste M, Waltimo O. Prognosis of patients with middle cerebral artery occlusion. Stroke 1976;7:482-5.

24 Snyder BD, Ramirez-Lassepas M. Cerebral infarction in young adults. Long term prognosis.

25 Janaki S, Baruah JK, Jayaram SR, Saxena VK, Sharma SR, Gulati MS. Stroke in the young: four-year study, 1968 to 1972 . Stroke 1975;6:318-20.

26 Ode B, Cronberg S. Infection and intracranial arterial thrombosis. Lancet 1976;ii:863-4.

27 Black DA, Maw DSJ. Toxic shock syndrome presenting as cerebral infarct. $\mathcal{F}$ Neurol Neurosur Psychiatry 1984;47:568.

28 Bourdette DN, Rosenberg NL, Yatsu FM. Herpes zoster ophthalmicus and delayed ipsilateral cerebral infarction. Neurology 1983;33:1428-32.

29 Kannel WB, Wolf PA, McGee DL, Dawber TR, McNamara P, Castelli WP. Systolic blood pressure, arterial rigidity, and risk of stroke. The Framingham study. JAMA 1981;245:1225-9.

30 Rössner S, Kjellin KG, Mettinger KL, Sidén $\AA$, Söderström CE. Normal serum-cholesterol bu low HDL cholesterol concentration in young patients with ischaemic cerebrovascular disease. Lancet 1978; $:$ :577-9.

31 Omata S, Yoshida M, Miyatake T, Sakamoto Y, Sakurabayashi I. Decreased HDL cholesterol in patients with cerebrovascular disease. Acta Neurol Scand 1979;60(suppl 72):460-1.

32 Nubiola AR, Masana L, Masdeu S, Rubies-Prat J. High-density lipoprotein cholesterol in cerebrovascular disease. Arch Neurol 1981;38:468.

33 Noma A, Matsushita S, Komori T, et al. High and low density lipoprotein cholesterol in myocardial and cerebral infarction. Atherosclerosis 1979;32:327-31.

34 Gordon T, Kannel WB, Castelli WB, Dawber TR. Lipoproteins, cardiovascular disease, and death. The Framingham study. Arch Intern Med 1981;141:1128-31.

35 Kohler O, Rasmussen K. Plasma lipids and lipoproteins in patients with cerebral infarct or transient cerebral ischemia. Acta Neurol Scand 1979;59:55-62.

36 Blackburn GG. Lipid metabolism in infection. Am $\mathcal{F}$ Clin Nutr 1977;30:1321-32.

37 Kerttula Y, Weber TH. Serum lipids in viral and bacterial meningitis. Scand $\mathcal{f}$ Infect Dis 1986;18:211-5.

38 Spodick KDH. Inflammation and onset of myocardial infarction. Ann Intern Med 1985;102 699-702.

39 Rasi V, Ikkala E, Valtonen V. Plasma B-thromboglobulin in severe infection. Thromb Res 1982;26:267-74

40 Theofilopoulos AN, Dixon FJ. The biology and detection of immune complexes. Adv Immuno 1979;28:89-220.

41 Minick CR, Murphy GE, Campbell WG Jr. Experimental induction of atheroarteriosclerosis by the synergy of allergic injury to arteries and lipid-rich diet. F Exp Med 1966;124:635-51.

42 Mathews JD, Whittingham S, Mackay IR. Autoimmune mechanisms in human vascular disease Lancet 1974;ii: 1423-7.

(Accepted 7 fanuary 1988)

\section{SHORT REPORTS}

\section{Percutaneous renal embolisation in renovascular hypertension}

Renal embolisation has proved to be useful in treating severe hypertension in patients receiving haemodialysis and after transplantation. ${ }^{12}$ It has also been used in few patients with renovascular hypertension, ${ }^{34}$ but these patients were evaluated for only a short period after embolisation.

We report the first prospective study of the long term effects of percutaneous renal embolisation on blood pressure and renal function in patients with severe renovascular hypertension not manageable with conventional treatments.

\section{Methods and results}

The table gives the clinical characteristics of the patients, and the results of diagnostic investigation and the effect of embolisation on blood pressure. The patients were selected for embolisation because it would have been impossible to perform percutaneous transluminal angioplasty or surgical bypass; they were at high risk from radical nephrectomy; they needed large resections of normal renal parenchyma; and their hypertension was poorly controlled by medical treatment or they had a high incidence of side effects, or both.

Total renal embolisation was carried out in six patients (cases 1-6). ${ }^{5}$ Renal ablation was limited to the portion of the kidney supplied by abnormal vessels in two patients with intralobular stenosis (cases 7 and 8 ). After embolisation blood pressure was recorded daily. Serum concentrations of urea and creatinine were measured the day before and two, four, and six days after embolisation. Patients were discharged and examined as outpatients one month later and every two months thereafter.

Five patients were regarded as cured (showing a decrease in blood pressure to $150 / 90 \mathrm{~mm} \mathrm{Hg}$ or less without antihypertensive treatment) and three were regarded as improved (showing a decrease in blood pressure to $150 / 90 \mathrm{~mm} \mathrm{Hg}$ or less with concomitant antihypertensive treatment). Five months after embolisation blood pressure rose progressively in one patient (case 4), who had refused repeat pyelography and arteriography.

Serum creatinine concentrations were slightly but significantly increased (from 85 (SE12) to $106(16) \mu \mathrm{mol} / 1 ; \mathrm{p}<0 \cdot 0025)$ two days after embolisation but returned

Clinical data on patients undergoing renal embolisation and effects of embolisation on blood pressure

\begin{tabular}{|c|c|c|c|c|c|c|c|c|}
\hline \multirow[b]{2}{*}{ Case No } & \multirow[b]{2}{*}{ Sex } & \multirow[b]{2}{*}{$\begin{array}{c}\text { Age } \\
\text { (years) }\end{array}$} & \multirow[b]{2}{*}{ Arteriographic features } & \multicolumn{2}{|r|}{ Before embolisation } & \multicolumn{3}{|c|}{ After embolisation } \\
\hline & & & & $\begin{array}{c}\text { Blood } \\
\text { pressure } \\
(\mathrm{mm} \mathrm{Hg})\end{array}$ & Daily treatment & Months & $\begin{array}{l}\text { Blood } \\
\text { pressure } \\
(\mathrm{mm} \mathrm{Hg})\end{array}$ & Daily treatment \\
\hline 1 & $F$ & 24 & Right renal hypoplasia & $160 / 120$ & Muzolimine $30 \mathrm{mg}$, captopril $150 \mathrm{mg}$ & 31 & $120 / 70$ & None \\
\hline 2 & $M$ & 44 & Atherosclerotic stenosis of right artery $(90 \%)$ & $240 / 130$ & $\begin{array}{l}\text { Metoprolol } 300 \mathrm{mg} \text {, clonidine } 300 \mu \mathrm{g}, \\
\text { frusemide } 25 \mathrm{mg} \text {, spironolactone } 200 \mathrm{mg}\end{array}$ & 49 & $130 / 80$ & None \\
\hline 3 & $M$ & 54 & $\begin{array}{l}\text { Thrombosis of main left renal artery and } \\
\text { collateral vessels }\end{array}$ & $220 / 120$ & $\begin{array}{l}\text { Methyldopa } 1000 \mathrm{mg} \text {, frusemide } 25 \mathrm{mg} \text {, } \\
\text { hydralazine } 75 \mathrm{mg}\end{array}$ & 7 & $120 / 80$ & $\begin{array}{l}\text { Labetalol } 100 \mathrm{mg} \text {, } \\
\text { chlorthalidone } 10 \mathrm{mg}\end{array}$ \\
\hline 4 & $M$ & 58 & $\begin{array}{l}\text { Thrombosis of main left renal artery and } \\
\text { collateral vessels }\end{array}$ & $240 / 140$ & $\begin{array}{l}\text { Nifedipine } 40 \mathrm{mg} \text {, captopril } 100 \mathrm{mg} \text {, } \\
\text { clonidine } 450 \mu \mathrm{g} \text {, hydralazine } 75 \mathrm{mg} \text {, } \\
\text { chlorthalidone } 25 \mathrm{mg}\end{array}$ & 5 & $150 / 80$ & $\begin{array}{l}\text { Enalapril } 20 \mathrm{mg} \text {, clonidine } \\
450 \mu \mathrm{g} \text {, hydralazine } 25 \mathrm{mg}\end{array}$ \\
\hline 5 & $M$ & 64 & $\begin{array}{l}\text { Thrombosis of main left renal artery and } \\
\text { collateral vessels }\end{array}$ & $180 / 100$ & $\begin{array}{l}\text { Methyldopa } 500 \mathrm{mg} \text {, clonidine } 300 \mu \mathrm{g} \text {, } \\
\text { hydrochlorothiazide } 50 \mathrm{mg}\end{array}$ & 7 & $120 / 70$ & None \\
\hline 6 & F & 50 & $\begin{array}{l}\text { Thrombosis of main right renal artery and } \\
\text { collateral vessels }\end{array}$ & $210 / 120$ & $\begin{array}{l}\text { Nifedipine } 30 \mathrm{mg} \text {, oxprenolol } 240 \mathrm{mg} \text {, } \\
\text { spironolactone } 100 \mathrm{mg}\end{array}$ & 33 & $150 / 80$ & None \\
\hline 7 & $\mathbf{M}$ & 7 & $\begin{array}{l}\text { Stenosis of intralobular artery at lower pole of left } \\
\text { kidney }\end{array}$ & $170 / 115$ & $\begin{array}{l}\text { Clonidine } 150 \mu \mathrm{g} \text {, hydralazine } 37.5 \mathrm{mg} \text {, } \\
\text { captopril } 75 \mathrm{mg}\end{array}$ & 17 & $120 / 70$ & Captopril $25 \mathrm{mg}$ \\
\hline 8 & $\mathrm{~F}$ & 13 & $\begin{array}{l}\text { Stenosis of intralobular artery at upper pole of } \\
\text { left kidney }\end{array}$ & $170 / 130$ & Atenolol $100 \mathrm{mg}$, hydralazine $75 \mathrm{mg}$ & 59 & $110 / 80$ & None \\
\hline
\end{tabular}

